www.volsu.ru

DOI: https://doi.org/10.15688/nsr.jvolsu.2020.2.2

UDC 502/504:631.4

LBC 26.222 .5

\title{
LOCATION DEPTH AND MINERALIZATION CHANGE OF GROUND WATERS IN IRRIGATED MEADOW-GREY SOILS OF THE SALYAN PLAIN
}

\author{
Parvana Chingiz kyzy Gaziyeva \\ Azerbaijan University of Architecture and Construction, Baku, Azerbaijan
}

\begin{abstract}
The article presents thorough information about the results of the research in the irrigated meadowgrey soils of the area where the grain was planted in the Salyan plain. The research shows that strong differences between the subsoil waters mineralization and change of their location levels were not observed in the experimental area in 2015-2018. However, in 2015 the location levels of subsoil waters changed by $2.40-2.55 \mathrm{~m}$, their mineralization was $-1.244-2.577 \mathrm{q} / 1$. These indicators changed to $2.40-2.60 \mathrm{~m}$ and $1.210-2.430 \mathrm{~d} / 1$ in $2016 ; 2.50-2.55 \mathrm{~m}$ and 1.030 $2.320 \mathrm{~g} / \mathrm{l}$ in $2017 ; 2.45-2.55 \mathrm{~m}$ and $1.183-2.159 \mathrm{~g} / \mathrm{l}$ in 2018. During the research the author studied the waters of Akusha canal, water-collector and drains which are used with the purpose of irrigation. It has been determined that their mineralization was $0.81 \mathrm{~g} / 1,6.663 \mathrm{~g} / \mathrm{l}$ and $4.834-5.242 \mathrm{~g} / \mathrm{l}$ in 2015 . These indicators changed as follows: $0.675 \mathrm{~g} /$ $1 ; 6.003 \mathrm{~g} / \mathrm{l}$ and $4.651-4.823 \mathrm{~g} / \mathrm{lin} 2016 ; 0.612 \mathrm{~g} / \mathrm{l} ; 5.872 \mathrm{~g} / \mathrm{l}$ and $4.731-4.602 \mathrm{~g} / \mathrm{l}$ in 2017 and $0.578 \mathrm{~g} / 1 ; 5.752 \mathrm{~g} / \mathrm{l}$ and $4.651-$ $4.513 \mathrm{~g} / \mathrm{l}$ in 2018. The agromeliorative measures have been offered for the purpose of subsoil waters decrease and their mineralization increase in the same zone taking into account all the indicators.

Key words: irrigating soils, ground waters, subsoil waters mineralization, salts amount, salts composition.

Citation. Gaziyeva P.Ch. kyzy. Location Depth and Mineralization Change of Ground Waters in Irrigated Meadow-Grey Soils of the Salyan Plain. Natural Systems and Resources, 2020, vol. 10, no. 2, pp. 15-25. (in Russian). DOI: https://doi.org/10.15688/nsr.jvolsu.2020.2.2
\end{abstract}

УДК 502/504:631.4

ББК 26.222 .5

\section{ГЛУБИНА ЗАЛЕГАНИЯ И ИЗМЕНЕНИЕ МИНЕРАЛИЗАЦИИ ГРУНТОВЫХ ВОД ОРОШАЕМЫХ ЛУГОВО-СЕРЫХ ПОЧВ САЛЬЯНСКОЙ СТЕПИ}

\author{
Парвана Чингиз кызы Газиева \\ Азербайджанский университет архитектуры и строительства, г. Баку, Азербайджан
}

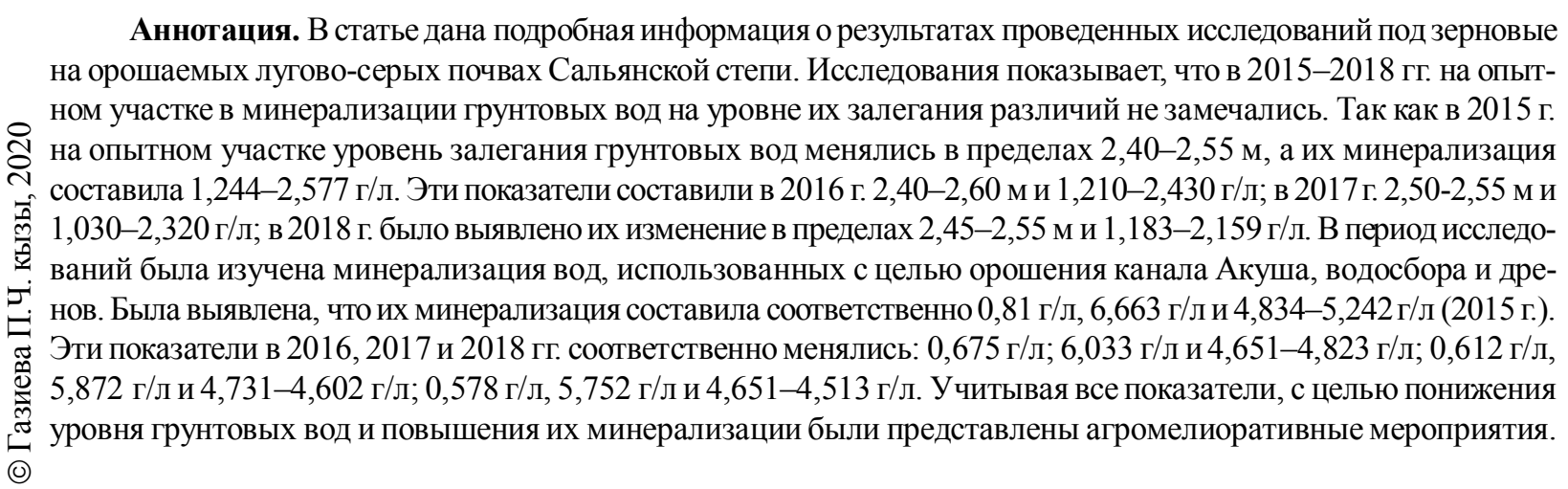


Ключевые слова: орошаемые земли, грунтовые воды, минерализация грунтовых вод, количество солей, состав солей.

Цитирование. Газиева П. Ч. кызы. Глубина залегания и изменение минерализации грунтовых вод орошаемых лугово-серых почв Сальянской степи // Природные системы и ресурсы. - 2020. - Т. 10, № 2. - С. 15-25. DOI: https://doi.org/10.15688/nsr.jvolsu.2020.2.2

Введение. Исследования показывают, что изучение уровня залегания грунтовых вод и изменение их минерализации является одним из основных факторов при оценке мелиоративного состояния этих территорий. Во время изучения количества солей и уровня залегания грунтовых вод, изменения динамики их минерализации, причин и явлений засоления и их устранения, эффективности дренажных систем были взяты и использованы исследования, проводимые В.Р. Волобуевым [2; 3]. В настоящее время используется предложенная им классификация, учитывающая засоленность почвы в зависимости от количества и типа солей, минерализации грунтовых вод и уровня их залегания. С целью их устранения изменений в почве в результате антропогенного воздействия (засоленность, солонцеватость, заболачивание и др.) разрабатываются рекомендации и внедряются системы агромелиоративных мероприятий. Проведенные за последние годы исследования показывают, что урожайность сельскохозяйственных культур таких факторов, как плодородие, воднофизические свойства, количество и типы солей, зависит и от уровня залегания грунтовых вод и их минерализации на протяжении многих лет [5; 6].

Исследования показывают, что в природе грунтовые воды, находясь в различных условиях с уклоном территории и имея естественный сток, слабо минерализованы. В зависимости от рельефа в некоторых местах грунтовые воды не имеют стока. В грунтовых водах таких территорий в течение долгого времени происходит растворение солей материнской породы, что приводит к их высокой степени минерализации. Такой процесс формируется на территориях с близким расположением грунтовых вод к поверхности земли в сочетании с высокой степенью испарения. Продолжительность таких процессов является причиной засоления почв в различной степени и приводит к непригодности таких земель. Регулирование уровня грунтовых вод при орошении сельскохозяйственных культур, возделываемых на территориях с близким залеганием грунтовых вод, не имеющих естественного стока, возможно с применением коллекторно-дренажных систем. В целом на орошаемых местах при засолении и в процессе формирования разных типов почв большое значение имеет химический состав грунтовых вод, а также их степень и типы минерализации. Исследования показывают, что при меньшей минерализации и щелочности в почве происходит засоление содового типа. При минерализации грунтовых больше 1,0 г/л и ее близким расположением к поверхности земли происходит активизация вредных для растений солей. Когда их уровень приближается к поверхности земли, наблюдается их увеличение, повышается процесс испарения и транспирации, в результате чего в почве происходит повторное засоление. Исследования показывают, что при сближении уровня грунтовых вод к поверхности земли большую роль в засолении почв играет такие факторы, как режим орошения, химический состав подаваемой на поле воды и др. [4; 7].

Многолетние исследования показывают, что в зависимости от расположения уровня грунтовых вод на исследуемой территории, их минерального состава и участие в формировании почв имеет место автоморфный, гидроморфный и полуавтоморфный режим [3; 4; 10]. В автоморфном режиме грунтовые воды питаются за счет орошаемых вод, свободно просачиваются в нижние слои, их естественный поток происходит интенсивно и обычно такие воды расположены на глубине 5,0-10,0 м над уровнем земли [6; 7]. В гидроморфном режиме почв растения питаются за счет грунтовых вод, условие естественного дренирования слабое, а минерализация низкая и расположены на глубине 1,0-2,0 м от поверхности земли [3; 10]. При полуавтоморфном режиме питание растений грунтовыми водами более активно, чем орошаемыми, поскольку они более минерализованы и 
не зависят от условий дренажа. В этом режиме требуется проведение мелиоративных мероприятий, а также меры борьбы против просачиваемых с оросительных каналов вод, постройка дренажных сетей и проведение других работ $[4 ; 6 ; 8]$. Исследования показывают, что в суглинистых почвах на вегетационный период среднее значение минерализации грунтовых вод меняется в пределах от 3,0 до 5,0 г/л, а их оптимальная глубина 2,5-3,0 метра. В равнине с низкой минерализацией грунтовых вод при засолении почв химический состав и минерализация имеет большое значение $[11 ; 12]$.

Исследования показывают, что при поливе водой, насыщенной гидрокарбонат-ионами Са и $\mathrm{Mg}$, впитываясь в почву вода соединяется с грунтовыми водами и превращается в воду с содержанием натри-гидрокарбоната и соды. В целом, естественным источником грунтовых вод является атмосферные осадки, вода с поверхности земли и сточные воды из окрестностей [3; 9]. На поверхности орошаемых земель влага большего водоудерживания образует свободную гравитационную воду, и свободная вода под действием силы тяжести движется вниз и в стороны. В самотечном поливе часть влаги, поступающая интенсивным потоком на поверхность земли, впитывается в почву, другая часть движется по поверхности земли. Когда поверхность земли маловодопроницаемая, влажная, с большим уклоном и со слабым растительным покровом, количество просачиваемой на поверхность воды больше, чем впитываемая вода [5; 6]. Было выявлено, что на орошаемых участках в режиме грунтовых вод происходят изменения: повышается интенсивность питания грунтовых вод за счет орошения, вследствие чего их уровень повышается. В местах с высоким дренированием в результате орошения наблюдается смыв солей из почвы. В почвах со слабым естественным дренированием из-за отсутствия искусственных дренажных систем, в зоне аэрации наблюдается повышение в почве количества солей и минерализации грунтовых вод. На орошаемых каналах из-за просачивания воды в грунтовых водах образуется местный напор, в результате чего меняется их режим. На этой территории естественная растительность заменяет- ся культурными растениями с низкой транспирацией, в результате чего уровень грунтовых вод повышается. Отсутствие коллекторно-дренажной системы, способствует устранению избытка воды с территорий со слабым стоком, при этом уровень грунтовых вод повышается, а процесс испарения усиливается, в результате чего минерализация грунтовых вод увеличивается и происходит повторное засоление почв. Своевременное применение дрен на этой территории дает возможность предотвратить повышение уровня и минерализации грунтовых вод. Исследования показывают, что на орошаемых территориях в изучении режима грунтовых вод одной из основных задач является определение их критической глубины. Как известно, для предотвращения повторного засоления почв и нормального роста растений в первую очередь нужно предотвратить превышение уровня грунтовых вод критической глубины. Критическая глубина грунтовых вод определяется в зависимости от гранулометрического состава, структурности, капиллярности, климатических факторов и др. Для слезообразных почв критическая глубина составляет 1,7-2,2 м при минерализации в 3,0 г/л, 3,0-3,5 г/л при глубине 2,2-3,0 м и 5,0-7,7 г/л при глубине $3,0-3,5$ метра. В тяжело суглинистых почвах эти показатели увеличивается на $20 \%$ [3; 6].

В.Р. Волобуев [3] и М.Г. Мустафаев [9; 11] в своих исследованиях показали, что в осенний период повторной засоленности почв не происходит. Авторы связывают это с расположением грунтовых вод на глубине 2,63,0 м, а критическая глубина на этих территориях $<2,0$ метров. По данным В.Р. Волобуева в почвах Мугано-Сальянского массива критическая глубина не должна превышать $1,75-$ 2,25 метра. На основе проведенных исследований было выявлено, что в солонцеватых и карбонатно-засоленных почвах целесообразно считать эту глубину немного больше, то есть в 2,5-2,8 метра. На участках с естественным стоком грунтовых вод, сравнивая их режим с подземным стоком, можно получить такие результаты: на участках с повышенным естественным стоком, то есть при количестве подводных стоков свыше 500 мм, годовое количество оросительных вод питающие грунтовые воды регулируется количеством про- 


\section{ЭкоЛОГИЯ И БИоЛОГИя}

текающей воды и на этих участках их уровень доходит до поверхности земли; на территориях с естественным дренированием почв при количестве фильтрованной воды 300 500 мм/г., она устраняется с территории подземными водами. Но при расположении уровня грунтовых вод близко к поверхности земли, поднимаясь наверх они влияют на физикохимическое свойство почвы, в результате чего их водно-воздушный режим нарушается [8]. Исследования показывают, что на территориях с интенсивным естественным стоком орошение слабо влияет на режим грунтовых вод. Причиной, способствующей этому, может являться высокая скорость протекающей с этой территории подземных стоков. В результате орошения уровень грунтовых вод на этой территории немного повышается, но не создает угрозу засоления почв. В почвах со слабым естественным стоком из-за орошения уровень грунтовых вод за короткое время поднимается до 2,0-3,0 м-а, что объясняется слабой скоростью продвижения подводных вод на этих участках. В последующее время благодаря испарению и частичного процесса транспирации, на этих участках уровень грунтовых вод относительно регулируется, в результате чего в уровне грунтовых вод формируется периодичный и многолетний режим [4; 11]. На естественно интенсивных и слабодренированных участках повышение уровня подземных вод требует проведения мелиоративных мероприятий перед орошением, что особенно целесообразно на слабодренированных участках, посредством установки временных дрен. Отсутствие мелиоративных мероприятий является причиной засоления, осолонцевания и в результате приводит к резкому снижению урожайности сельскохозяйственных культур. Изучение режима грунтовых вод на орошаемых землях показывает, что, на участках с естественным стоком, минерализация грунтовых вод меньше, а в течение всего периода наблюдается небольшие изменения. Минерализация грунтовых вод увеличивается на участках со слабым стоком, этот процесс наблюдается в большинстве случаев на участках без стока. На этих участках под действием орошения на уровне грунтовых вод происходит процесс временного опреснения. После завершения орошения пресная вода испаря- ется и наблюдается прежнее состояние грунтовых вод, то есть повышение их минерализации $[6 ; 9]$.

Объекты исследования и методы. Одним из основных задач исследования является изучение динамики изменения залегания и минерализации грунтовых вод. В связи с этим на орошаемых лугово-серых почвах Сальянской степи (на опытном участке) в 2015-2018 гг. были проведены исследования и сравнительный анализ полученных результатов. А также были изучены количество солей в почве и состояние оросительных каналов территории, изменение минерализации дренажных вод. Исследования были выполнены в полевых и лабораторных условиях по методике полевого опыта Б.А. Доспехова. Во время исследований все химические анализы проводились по методике, широко используемой в почвоведении [1].

Результаты и обсуждения. Исследования показывают, что на дренированных участках уровень залегания грунтовых вод по мере приближения к дренам увеличивается. В результате вегетационных орошений и несмотря на повышение уровня грунтовых вод, после проведения орошения их уровень снижается. После завершения каждого орошения через 5-8 дней скорость снижения уровня грунтовых вод составляет $1,0-0,8 \mathrm{~cm} /$ дней. Проведенные исследования показывают, что грунтовые воды в степной части расположены в основном на глубине 1-2,0 м-а от поверхности земли, а в малых местах на глубине $>2,0$ м-а. В целом уклон поверхности грунтовых вод направлен в сторону реки Кура, а оттуда к морю. Исследования показывают, что самая большая амплитуда изменения уровня грунтовых вод наблюдается на орошаемых участках. На орошаемых участках уровень грунтовых вод и минерализация беспрерывно меняется в зависимости от режима работы каналов, влияния орошения атмосферных осадков, испарения, степени дренирования. На интенсивно орошаемых участках амплитуда изменения их уровня в течение сезона составляет 1,0-1,5 м, а иногда 2,0-2,5 м. Если грунтовые воды расположены глубже, ее амплитуда меняется в пределах $0,5-1,0$ м; на приречных аллювиальных глубинах меняется в пределах 1,0-3,0 метров. В целом, изучая ми- 
нерализацию грунтовых вод и принимая за основу почвенно-климатические условия, нужно обратить особое внимание на изменение минерализации орошаемых вод и их состава по сезонам. Исследования показывают, что в пониженных участках степей, минерализация составляет 0,5-1,0 г/л, а в речных и ближе к крупным оросительным каналам местах, меняется в пределах 2,0-5,0 г/л. Количество солей, приближаясь к центру степи и оттуда к Каспийскому морю, увеличивается, а в минусовой высоте массива их минерализация очень высокая (10-50 г/л), в некоторых местах составляет до 100 г/л, и только в период орошения их количество немного снижается. [9]. Различия грунтовых вод по химическому составу было широко описано в исследованиях В.Р. Волобуева [2; 3]. На основе проведенных исследований было выделено 3 типа грунтовых вод: гидрокарбонатный, сульфатный и хлоридный. Гидрокарбонатные воды в основном распространены в степной зоне, в долине реки Кура и больших оросительных каналов (Акуша и др.), а их минерализация составляет 10 г/л. Хлоридные воды распространены в центре и немного восточнее Сальянской степи, а их минерализация составляет 20-25 г/л и больше. Сульфатные воды расположены в подгорной части степи, уровень минерализации выше среднего и меняется в пределах 1020 г/л. Помимо этих вод на этих территориях часто встречаются натриевые и кальций карбонатные воды. Натриевые и кальций сульфатные воды встречаются редко.

В последнее время под влиянием антропогенных факторов происходит изменение почв Сальянской степи и для улучшения их состояния проводится комплексные мероприятия [3; 11]. Как мы знаем, одним из факторов влияющий на мелиоративное состояние почв является близкое расположение минерализованных грунтовых вод к поверхности земли (1,5-2,0 м). Так как минеральные грунтовые воды, расположены на глубине 1,5-2,0 м то они влияют на повышение степени засоленности почв, а также на развитие растений. На территории Сальянского района орошаемые каналы и грунтовые воды вдоль реки Кура под влиянием надземных вод менее минерализованы, а по мере отдаления, этот показатель постепенно увеличивается. На орошаемых районах и на территории побережья минерализация грунтовых вод меняется в диапазоне 10-25 г/л. Проведенные многолетние исследования показывают, что в Сальянской степи в местах с удовлетворительным состоянием коллекторно-дренажных оросительных систем, уровень грунтовых вод ниже критической глубины, а их минерализация находиться на низком уровне. В некоторых участках, состояние которых неудовлетворительно, наблюдается высокий уровень грунтовых вод и близкое расположение к поверхности земли.

Исследования показывают, что участки на территории Сальянского района имеют глубину грунтовых вод от поверхности земли меньше 1,0 м-а и составляют 10200 га, а на 1,3-3,0 м-а составляет 28950 га. Минерализация грунтовых вод меняется в среднем диапазоне 4,35-23,16 г/л. на основе проведенных исследований было выявлено, что в местах с повышенным количеством солей в несколько раз завышен показатель минерализованности. Количество солей в почве составляет 0,25$0,50 \%$, а количество грунтовых вод составляет -1-3 г/л; а при большем количестве солей эти показатели больше 3,0 г/л. Результаты исследований даны в таблице 1. Как видно из таблицы 1 в период исследований минерализованность грунтовых вод меняется в пределах 1,040-2,577 г/л. В составе солей встречается ионы $\mathrm{SO}_{4}$, ионы $\mathrm{Cl}$, ионы $\mathrm{HCO}_{3}$, их количество соответственно составило 0,2790,806 г/л; 0,131-1,102 г/л; 0,219-0,419 г/л. Что касается содержания катионов в составе солей на первом месте $\mathrm{Na}+\mathrm{K}$, потом Са и $\mathrm{Mg}$. Их содержание в период исследований соответственно менялось в пределах 0,134-0,695 г/л; $0,090-0,180$ г/л и 0,060-0,180 г/л. В конце исследования (2018) на опытном участке причиной относительного уменьшения минерализации грунтовых вод послужило очищение некоторых коллекторно-дренажных систем: использование временных дренов и водосборов, минеральных и органических удобрений. Как видно из таблицы, в 2015-2018 гг. на этих территориях изменение минерализации грунтовых вод соответственно составило 1,0402,577 г/л. Результаты анализов показывают, что в грунтовых водах в составе солей из анионов $\mathrm{SO}_{4}$ превышает значение, потом анионы $\mathrm{Cl}-\mathrm{a}$ и $\mathrm{HCO}_{3}$. Их показатели менялись соот- 
ветственно: 0,230-13,261; 0,071-9,065 г/л и $0,122-1,842$ г/л. Из катионов на первом месте $\mathrm{Na}+\mathrm{K}$, потом $\mathrm{Mg}$ и $\mathrm{Ca}$, а их количество соответственно составляет 0,041-0,701 г/л; 0,0360,192 г/л; 0,100-0,180 г/л. Результаты исследований показывают, что в 2018 году в грунтовых водах 1-го разреза наблюдался ион$\mathrm{CO}_{3}$. На этом месте показатель иона $\mathrm{CO}_{3}$ составил 0,030 г/л, а в других местах не наблюдался, что объясняется использованием этих земель долгое время под сельхозкультуры, проведением некоторых агротехнических и агромелиоративных мероприятий, подачи воды по нормам требования растениями, а в общем правильное использование земель является причиной снижения их показателей. Многолетние исследования показали, что в Сальянской степи на территории, где коллекторно-дренажная и оросительная система работают удовлетворительно, наблюдалась высокая степень минерализация грунтовых вод, а уровень расположен ближе к поверхности земли.

В целом исследованием выявлено, что в почвах, где количество солей высокое, минерализация грунтовых вод несколько больше, так как в почвах количестве солей составляет $0,25-0,50 \%$. Если количество грунтовых вод 1-3 г/л, то в местах выше $0,5 \%$ этот показатель больше 3,0 г/л. Все эти процессы привели к негативным явлениям, таким как засоление почв, а в некоторых местах повторное засоление и др. В результате было выявлено, что уро- жайность сельхозкультур снизилась на 15-25 \%. Исследование показывает, что в Сальянской степи в местах с повышенным количеством солей в почве уровень грунтовых вод расположен близко к поверхности земли, их минерализованность в несколько раз выше, чем на прилегающих территориях. Одной из причин их расположения ближе к поверхности земли является неудовлетворительная работа коллекторно-дренажных систем и некоторых оросительных систем на этой территории $[3 ; 11 ; 12]$.

Это в свою очередь создает удобный тепловой, воздушный и солевой режим для нормального роста растений. В исключительных случаях без применения дрена на засоленных территориях путем промывки можно привести почву в удовлетворительное состояние и предотвратить повторное засоление. Это требует выполнения трех основных правил: наличие водопроницаемости почвы и грунта, территория должна быть высокой, грунтовые воды должны располагаться на глубине более 5 м от поверхности земли и должен быть естественный сток. В естественных условиях такие территории с такими условиями редко встречаются. Значительная часть территорий пустынной, полупустынной и степной зоны с точки зрения мелиорации являются неблагоприятными. В естественных условиях на территориях в той или иной степени наблюдается засоление почв и грунтов, в

Таблища 1

Изменение минерализации грунтовых вод на опытном участке, 2015-2018 гг.

\begin{tabular}{|c|c|c|c|c|c|c|c|c|c|c|}
\hline \multirow{2}{*}{$\begin{array}{l}\text { № } \\
\text { pa3- } \\
\text { реза }\end{array}$} & \multirow{2}{*}{$\begin{array}{c}\text { Глу- } \\
\text { бина, } \\
\text { см }\end{array}$} & \multirow{2}{*}{$\begin{array}{c}\text { Плотный } \\
\text { остаток, } \\
\text { г/л } \\
\end{array}$} & \multicolumn{7}{|c|}{$\Gamma / \Omega$} & \multirow{2}{*}{$\begin{array}{c}\text { Сумма } \\
\text { солей, } \\
\text { Г/л }\end{array}$} \\
\hline & & & $\mathrm{CO}_{3}$ & $\mathrm{HCO}_{3}$ & $\mathrm{Cl}$ & $\mathrm{SO}_{4}$ & $\mathrm{Ca}$ & $\mathrm{Mg}$ & $\mathrm{Na}+\mathrm{K}$ & \\
\hline 1 & 2 & 3 & 4 & 5 & 6 & 7 & 8 & 9 & 10 & 11 \\
\hline \multicolumn{11}{|c|}{ 2015-ci il } \\
\hline 1 & 2,45 & 1.340 & - & 0.244 & 0.266 & 0.444 & 0.140 & 0.084 & 0.155 & 1.333 \\
\hline 3 & 2,40 & 1.250 & - & 0.226 & 0.160 & 0.502 & 0.120 & 0.060 & 0.176 & 1.244 \\
\hline 4 & 2,20 & 2.466 & - & 0.293 & 0.753 & 0.683 & 0.180 & 0.180 & 0.373 & 2.462 \\
\hline 6 & 2,25 & 2.451 & - & 0.335 & 0.603 & 0.773 & 0.140 & 0.144 & 0.451 & 2.446 \\
\hline 7 & 2,45 & 2.491 & - & 0.421 & 0.614 & 0.625 & 0.100 & 0.024 & 0.695 & 2.480 \\
\hline 9 & 2,50 & 2.600 & - & 0.439 & 0.628 & 0.707 & 0.140 & 0.096 & 0.567 & 2.577 \\
\hline \multicolumn{11}{|c|}{ 2018-ci il } \\
\hline 1 & 2,50 & 1.205 & - & 0.256 & 0.124 & 0.485 & 0.100 & 0.084 & 0.134 & 1.183 \\
\hline 3 & 2,45 & 1.141 & - & 0.244 & 0.131 & 0.444 & 0.120 & 0.060 & 0.137 & 1.136 \\
\hline 4 & 2,30 & 1.927 & - & 0.409 & 0.305 & 0.651 & 0.100 & 0.072 & 0.387 & 1.924 \\
\hline 6 & 2,35 & 1.957 & - & 0.396 & 0.327 & 0.650 & 0.100 & 0.084 & 0.396 & 1.953 \\
\hline 7 & 2,40 & 2.342 & 0.060 & 0.219 & 1.112 & 0.528 & 0.090 & 0.162 & 0.018 & 2.159 \\
\hline 9 & 2,45 & 2,058 & - & 0.409 & 0.371 & 0.651 & 0,140 & 0.072 & 0.387 & 2.030 \\
\hline
\end{tabular}


большинство случаев водопроницаемость слабая, грунтовые воды расположены близко к поверхности земли, а естественный сток незначителен.

О роли дренажа в процессе очистки от растворимых солей, требующий промывки засоленных почв и грунтовых слоев, было предложено впервые в 1960 г. А.Н. Костяковым. В настоящее время в республиках Средней Азии и Загафгазии, Южного Казахстана на пригодных с точки зрения мелиорации на непригодных орошаемых территориях широко применяется дренажные сооружения [10]. В настоящее время в республике на территории используется в 448,4 тыс. га дренажная сеть в длиною 21 тыс. га. Исследования показывают, что в зависимости от сезона в устраненных дренами водах минерализация бывает разной. В зимний период в водах устраненных дренами водах минерализация бывает разной. В зимний период она низкая, а в летний период немного выше, что объясняется проведением вегетационного орошения и зимнего арата. В весенний период минерализация вынесенных дреном вод незначительно повышается, в осенний период минерализация дренажных вод имеет высокий уровень по сравнению с другими сезонами года. Исследования показывают, что при освоении мелиорируемых засоленных почв эффективность действующей коллекторно-дренажной сети определяется не только количеством вынесенной в определенное время с участка грунтовых вод, но и от процесса снижения минерализации этих вод, потому что уменьшение минерализации грунтовых или же входящих в дрен вод показывает уменьшение засоленности почв.

М.Г. Мустафаев [8; 11] ссылаясь на исследования, проведенные на фоне дренажа, показал, что в годы использования опытных участков под осенние растения, изменение минерализации отведенных дреном отличается от периода использования участков под хлопок. По результатам на участке под зерновые самый низкий показатель минерализации дренажных стоков наблюдается весной, а высокий - осенью. А также минерализация дренажных вод в годы использования под зерновые очень высокое, чем под хлопковые. Автор объясняет этот процесс большей потребностью в вегетационный период осенних зерновых к воде, чем хлопковые.

Х.Ф. Джафаров и А. Дж. Гашимов в своих исследованиях показали, о необходимости во время мелиорации засоленных почв КураАразской низменности правильного использо-

Таблииа 2

Изменение минерализации грунтовых вод на опытном участке, 2016-2017 гг.

\begin{tabular}{|c|c|c|c|c|c|}
\hline \multirow{2}{*}{ Наименование } & $\mathrm{CO}_{3}$ & $\mathrm{HCO}_{3}$ & $\mathrm{CI}$ & $\mathrm{SO}_{4}$ & \multirow{2}{*}{$\begin{array}{c}\text { Плотный } \\
\text { остаток, г/л }\end{array}$} \\
\hline & Г/л & г/л & Г/л & $\Gamma / \pi$ & \\
\hline \multicolumn{6}{|c|}{2015} \\
\hline Водосбор-1 & - & 0,735 & 2,414 & 2,337 & 6,663 \\
\hline Канал Акуша & - & 0,198 & 0,082 & 0,215 & 0,815 \\
\hline $\mathrm{D}_{1}$ & - & 0,545 & 1,384 & 1,223 & 5,242 \\
\hline $\mathrm{D}_{2}$ & - & 0,532 & 1,305 & 1,207 & 4,834 \\
\hline \multicolumn{6}{|c|}{2016} \\
\hline Водосбор-1 & - & 0,695 & 2,363 & 2,210 & 6,033 \\
\hline Канал Акуша & - & 0,174 & 0,071 & 0,201 & 0,675 \\
\hline $\mathrm{D}_{1}$ & - & 0,523 & 1,334 & 1,116 & 4,823 \\
\hline $\mathrm{D}_{2}$ & - & 0,508 & 1,271 & 1,103 & 4,651 \\
\hline \multicolumn{6}{|c|}{2017} \\
\hline Водосбор-1 & - & 0,671 & 2,293 & 2,113 & 5,872 \\
\hline Канал Акуша & - & 0,190 & 0,080 & 0,208 & 0,612 \\
\hline $\mathrm{D}_{1}$ & - & 0,505 & 1,313 & 1,123 & 4,731 \\
\hline $\mathrm{D}_{2}$ & - & 0.489 & 1,264 & 1,009 & 4,602 \\
\hline \multicolumn{6}{|c|}{2018} \\
\hline Водосбор-1 & - & 0,633 & 2,241 & 2,004 & 5,752 \\
\hline Канал Акуша & - & 0,163 & 0,069 & 0,198 & 0,578 \\
\hline $\mathrm{D}_{1}$ & - & 0,485 & 1,283 & 1,094 & 4,651 \\
\hline $\mathrm{D}_{2}$ & - & 0,467 & 1,235 & 1,078 & 4,513 \\
\hline
\end{tabular}




\section{ЭКОЛОГИя И БИОЛОГИЯ}

вания почв, систематической очистки коллекторно-дренажных систем и организации ремонтно-восстановительных работ в нужной части дрена, в местах с повышенным количеством солей проведения промывки почв. В случае проведения вышеуказанных и агротехнических мероприятий можно добиться количества солей в почве и получения высокого урожая от сельскохозяйственных растений. В современном орошении земледелия при расположении уровня минерализованных грунтовых вод ближе к поверхности земли (выше критической глубины) и в условиях гидрогеологии, когда не возможно придерживаться режима грунтовых вод нужной для роста растений, для снижения уровня грунтовых вод к нижним слоям почв, постройка дренажной сети необходим. Как мы знаем, одним из основных условий для хлопковых районов, является расположение грунтовых вод на глубине ниже 2,5-3 м от поверхности земли. В этом случае после орошения в течение 7-8 дней можно допустить расположение грунтовых вод ближе к поверхности земли на 1,2-1,5 метра. При невозможности создания этих условий естественным путем, для снижения уровня грунтовых вод нужно применят нетрадиционные мероприятия. Несмотря на большую роль в снижении уровня грунтовых вод, дренаж не может считаться универсальным методом борьбы. Помимо этого, для создания на орошаемых землях благоприятной структуры необходимо применение агротехнических мероприятий. Для решения мелиоративных вопросов территории кроме оросительной сети, необходимо постройки дренажной системы.

Типы дренажной сети, такие как закрытые, открытые и комбинированные в одинаковой степени имеют большое значение. Применение открытого и закрытого типа дренажной сети зависит от гидрогеологических, агрономических условий и от междренного расстояния.

Их способность водоподачи зависит от глубины дрена. При большой глубине дрена, свыше требуемой нормы, образуется высокое гидростатистическое давление, которое влияет на дренажный модуль. Соответственно по гидрогеологическим условиям глубина дренов не должна быть ниже 2,5-3,5 м-а. На орошаемой территории междренное расстояние зависит от их глубины, способности фильтрации, количества солей, гидрогеологических условий и от понижения после промывки уровня грунтовых вод. При таких условиях в Азербайджане и в других республиках на основании проведенных исследований и по результатам практических работ нижний предел междренного расстояния был установлен в диапазоне 200-250 м [3; 6; 9]. Во время исследований на опытном участке было проведен визуальный просмотр дренов и изучено их современное состояние. Были рассмотрены в них поток воды (скорость) и разрушение склонов, работа способность гидротехнических сооружений (водопропускающие сооружения, трубопроводы, заполнение истока дрена и др.) Изучение изменения минерализации вод дренажом, дренов, водосборов и оросительных каналов является одним из основных задач исследований. Поэтому во время исследований были взяты водные пробы и проведены химические анализы.

Результаты анализов были сравнены с предыдущими (2015) показателями исследований (см. табл. 3). Как видно из таблицы их химический состав разный. В составе дренажных вод ионы CO3 не наблюдались, а концентрация ионов хлора увеличилась. Как видно из таблицы в 2015-2018 гг. на опытном участке в составе воды показатель ионов Cl-a менялся до 1,235-1,384 г/л. Другим превышавшим по концентрации является ион являлся $\mathrm{SO}_{4}$. Его концентрация в период исследований менялась в пределах 1,078-1,223 г/л. В этих водах показатель ионов $\mathrm{HCO}_{3}$ тоже был разным и в 2015-2018 гг. и менялся в переделах 0,467-0,545 г/л. А в дренах их минерализация в период исследований менялась в пределах 4,513-5,242 г/л.

Как видно из таблицы 3 в водосборе опытного участка показатель минерализации воды был высоким, чем в дренах и менялся от 5,752 г/л до 6,663 г/л. В водосборах ионов $\mathrm{CO}_{3}$ не встречались. В водосборе в составе воды ионы Cl-a превышают и их показатель менялся от 2,241 г/л до 2,414 г/л. После иона $\mathrm{Cl}$-а превышает ионы $\mathrm{SO}_{4}$ и его показатель менялся от 2,004 до 2,337 г/л. Исследования показывают, что при допустимых нормах минерализации и состава оросительных вод, это положительно влияет на количество солей в почве, и на урожайность сельхозкультур. 
П. Ч. кызы Газиева. Глубина залегания и изменение минерализации

Таблица 3

Изменение минерализации на дренах, водосборах и орошаемых водах опытного участка, 2015-2018 гг.

\begin{tabular}{|c|c|c|c|c|c|c|}
\hline \multirow{2}{*}{$\begin{array}{c}\text { № } \\
\text { paзреза }\end{array}$} & \multirow{2}{*}{$\begin{array}{c}\text { Глубина, } \\
\text { см }\end{array}$} & $\mathrm{CO}_{3}$ & $\mathrm{HCO}_{3}$ & $\mathrm{SO}_{4}$ & $\mathrm{Cl}$ & \multirow{2}{*}{$\begin{array}{c}\text { Минерализация, } \\
\text { г/л }\end{array}$} \\
\hline & & Г/л & Г/л & Г/л & Г/л & \\
\hline 1 & 2 & 3 & 4 & 5 & 6 & 7 \\
\hline \multicolumn{7}{|c|}{2016 год } \\
\hline 1 & 2,40 & нет & 0,262 & 0,490 & 0,175 & 1,325 \\
\hline 3 & 2,25 & - & 0,256 & 0,452 & 0,167 & 1,210 \\
\hline 4 & 2,45 & - & 0,213 & 0,362 & 0,091 & 2,380 \\
\hline 6 & 2,55 & - & 0,317 & 0,806 & 0,770 & 2,430 \\
\hline 7 & 2,50 & - & 0,439 & 0,708 & 0,628 & 2,400 \\
\hline 9 & 2,50 & нет & 0,424 & 0,634 & 0,343 & 2,350 \\
\hline \multicolumn{7}{|c|}{2017 год } \\
\hline 1 & 2,45 & нет & 0,226 & 0,410 & 0,131 & 1,030 \\
\hline 3 & 2,50 & - & 0,262 & 0,494 & 0,163 & 1,040 \\
\hline 4 & 2,30 & - & 0,281 & 0,279 & 0,138 & 1,840 \\
\hline 6 & 2,30 & - & 0,415 & 0,703 & 0,343 & 2,320 \\
\hline 7 & 2,45 & - & 0,305 & 0,724 & 0,745 & 2,316 \\
\hline 9 & 2,50 & нет & 0,414 & 0,633 & 0,621 & 2,205 \\
\hline
\end{tabular}

С целью изучения минерализации и состава воды, используемого на опытном участке, были взяты в период исследований водные пробы с оросительного канала (канал Акуша) и проведены химические анализы.

Результаты анализов показывают, что в период исследований минерализация используемой воды для орошения менялся в пределах 0,578 г/л $-0,818$ г/л. Учитывая, что минерализация оросительных вод не превышала 1,0 г/л, использование этих вод для орошения не является опасным. Как видно из таблицы 3 в период исследований в составе оросительной воды превышает ионы $\mathrm{SO}_{4}$ - и менялся в пределах 0,447 - 0,410 г/л. После иона $\mathrm{SO}_{4}$ в ее составе превышали ионы $\mathrm{HCO}_{3}$, после ионы $\mathrm{Cl}$-а. В период исследования показатель ионов $\mathrm{HCO}_{3}$ менялся в пределах 0,163-0,198 г/л, а показатель ионов Cl-a соответственно 0,0690,082 г/л. Вышеуказанные факторы можно улучшить путем проведения на этих территориях комплексных агромелиоративных и агротехнических мероприятий. Поэтому в первую очередь, используя эти факторы можно добиться повышения эффективности коллекторно-дренажной системы, а после решения вопроса повышения урожайности сельскохозяйственных растений.

Выводы. Исследования показали, что в минерализации грунтовых вод и на уровне их залегания резких различий не замечались. Так как если в 2015 г. уровень залегания грунтовых вод составил 2,40-2,55 м, то эти показатели менялись соответственно 2,45-2,55 м. Было выявлено, что минерализация грунтовых вод менялась соответственно от 1,244-2,577 г/л до 1,136-2,159 г/л. Минерализация грунтовых вод в 2016-2017 гг. немного снизилась, а в 2018 г. повысилаль.

В составе грунтовых вод показатели ионов сульфата преобладает, чем другие показатели. Поэтому они относятся к сульфатным типам грунтовых вод (после ионов сульфата преобладает ионы хлора).

С целью повышения уровня грунтовых вод на опытном участке необходимо обеспечение эффективной деятельности дренажа. Было предложено выращивание на этих участках солеустойчивых растений и совместно с агротехническими мероприятиями проведение агромелиоративных мероприятий.

\section{СПИСОК ЛИТЕРАТУРЫ}

1. Аринушкина, Е. В. Руководства по химическому анализу почв / Е. В. Аринушкина. - М. : Изд-во МГУ, 1970. - 488 с.

2. Волобуев, В. Р. Генетические формы засоления почв Кура-Араксинской низменности / В. Р. Волобуев. - Баку: Изд-во Акад. наук АзССР, 1965. - 248 с.

3. Волобуев, В. Р. Расчет промывки засоленных почв / В. Р. Волобуев. - М. : Колос, 1975. - 65 с. 
4. Искендеров, М. Я. Промывка засоле́нных почв на фоне применения химиических мелиорантов / М. Я. Искендеров // Мелиорация и водное хозяйство. - 2011. - № 4. - С.21-23.

5. Исрафилов, Ю. Г. Формирование, прогноз и рациональное использование ресурсов пресных подземных вод предгорных равнин Азербайджанской Республики: автореф. ... д-ра г.-м. наук / Исрафилов Юсиф Габиб. - Баку, 2005. - 48 с.

6. Мустафаев, М. Г. Причины снижения эффективности сельхозпроизводства на землях Азербайджана / М. Г. Мустафаев // Агрохимический вестник. - 2012. - № 3. - С. 43-45.

7. Мустафаев, М. Г. Мелиоративное состояние орошаемых засоленных почв Мугань-Сальянского массива Кура-Араксинской низменности / М. Г. Мустафаев // Вестник Белорусской государственной сельскохозяйственной академии. 2014. - № 1. - С. 127-131.

8. Мустафаев, М. Г. Долгосрочный прогноз мелиоративных мероприятий в республике Азербайджан / М. Г. Мустафаев // Агрохимический вестник. - 2014. - № 3. - С. 34-37.

9. Мустафаев, М. Г. Исследование воднофизических свойств орошаемых лугово-серых почв на опытном участке в условиях Азербайджана / М. Г. Мустафаев, П. Ч. Газиев // Экология и строительство. - 2019. - № 3. - С. 49-54.

10. Ecological Quality Assessment of Drainage Water of Irrigated Lands at Syr Dariya Middle Course / R.K. Bekbayev [et al.] // Orient J Chem. - 2015. Vol. 31, № 4. - P. 237-248. - DOI: http://dx.doi.org/ 10.13005/ojc/31.Special-Issue1.29.

11. Mustafaev, M. G. Criteriya for the Evaluation of Reclamation Status of Soils in the Mugan-Salyan Massif / M. G. Mustafaev // Journal of Water and Land Development. - 2015. - № 24 (I-III). - P. 21-26.

12. Mustafaev, M. G. Impact of Microrelief on Salinization Process in the Soils of the Research Zone (on the Example of the Shirvan Steppe) / M. G. Mustafaev, G. G. Dzhebrailova, F. M. Mustafaev // Soils and Agrochemistry. - 2017. - № 3. - P. 31-36.

\section{REFERENCES}

1. Arinushkina E.V. Rukovodstva po khimicheskomu analizu pochv [Guidelines for Chemical Analysis of Soils]. Moscow, MGU Publ., 1970. 488 p.

2. Volobuev V.R. Geneticheskie formy zasoleniya pochv Kura-Araksinskoy nizmennosti [Genetic Forms of Soil Salinization in the Kura-Araksin Lowland]. Baku, Akad. naukAzSSR Publ., 1965. 248 p.

3. Volobuev, V.R. Raschet promyvki zasolennykh poch $v$ [The Calculation of Flushing Saline Soils]. Moscow, Kolos Publ., 1975. 65 p.
4. Iskenderov M.Ya. Promyvka zasolennykh pochv na fone primeneniya khimicheskikh meliorantov [Saline Soils Flushing During Treatment the Chemical Ameliorants]. Melioratsiya $i$ vodnoe khozyaystvo. [Irrigation and Water Management], 2011, no. 4, pp. 21-23.

5. Israfilov Yu.G. Formirovanie, prognoz $i$ ratsionalnoe ispolzovanie resursov presnykh podzemnykh vod predgornykh ravnin Azerbaidzhanskoi Respubliki: avtoref. ... d-ra g.-m. nauk [Formation, Forecast and Rational Use of Fresh Underground Water Resources in the Foothill Plains of the Republic of Azerbaijan. Dr. geol. and mineral. sci. abs. diss.]. Baku, 2005. 48 p.

6. Mustafayev M.G. Prichiny snizheniya effektivnosti selkhozproizvodstva na zemlyakh Azerbaydzhana [Causes of Agricultural Efficiency' Decrease on Lands of Azerbaijan]. Agrokhimicheskiy vestnik [Agrochemical Herald], 2012, no. 3, pp. 43-45.

7. Mustafaev M.G. Meliorativnoe sostoianie oroshaemykh zasolennykh pochv Mugan-Salyanskogo massiva Kura-Araksinskoy nizmennosti [Reclamation Status of Irrigated Saline Soils of the Mugan-Salyan Massif of the Kura-Araksin Lowland]. Vestnik belorusskoy gosudarstvennoy selskokhozyaystvennoy akademii [Bulletin of the Belarussian State Agricultural Academy], 2014, no. 1,pp. 127-131.

8. Mustafaev M.G. Dolgosrochnyi prognoz meliorativnykh meropriyatiy $\mathrm{v}$ respublike Azerbaydzhan [Long-Term Forecast for Meliorative Procedures in the Azerbaijan Republic]. Agrokhimicheskiy vestnik [Agrochemical Herald], 2014, no. 3, pp. 34-37.

9. Bekbayev R.K., Balqabayev N.N., Zhaparkulova Y.D., Bekbayev N.R. Ecological Quality Assessment of Drainage Water of Irrigated Lands at Syr Dariya Middle Course. Oriental Journal of Chemistry, 2015, vol. 31, no. 4, pp. 237 248. DOI: http://dx.doi.org/10.13005/ojc/31.SpecialIssue 1.29.

10. Mustafaev M.G., Gaziyev P. Ch. Issledovanie vodno-fizicheskikh svoystv oroshaemykh lugovoserykh pochv na opytnom uchastke $\mathrm{v}$ usloviyakh Azerbaidzhana [Research of Water-Physical Properties of Irrigated Meadow-Gray Soils (on Experienced Plot) Under the Conditions of Azerbaijan]. Ekologiya $i$ stroitelstvo [Ecology and Construction], 2019, no. 3, pp. 49-54.

11. Mustafaev M.G. Criteriya for the Evaluation of Reclamation Status of Soils in the Mugan-Salyan massif. Journal of Water and Land Development, 2015, no. 24 (I-III), pp. 21-26.

12. Mustafaev M.G., Djebrailova G.G., Mustafayev F.M. Impact of Microrelief on Salinization Process in the Soils of the Research Zone (on the Example of the Shirvan Steppe). Soils and agrochemistry, 2017, no. 3, pp. 31-36. 


\section{Information About the Author}

Parvana Chingiz kyzy Gaziyeva, Assistant Lecturer, Azerbaijan University of Architecture and Construction, A. Sultanova St, 11, AZ 1073 Baku, Azerbaijan, pervane.qaziyeva@mail.ru.

\section{Информация об авторе}

Парвана Чингиз Газиева, ассистент, Азербайджанский университет архитектуры и строительства, ул. А. Султанова, 11, AZ 1073 г. Баку, Азербайджан, pervane.qaziyeva@mail.ru. 